\title{
A SURVEY ON FINANCIAL AND MANAGEMENT ACCOUNTING PRACTICES AMONG SMALL AND MEDIUM ENTERPRISES IN MALAYSIA
}

\author{
Che Ruhana Isa, Zakiah Saleh, Noor Sharoja Sapiei
}

\begin{abstract}
In the current business environment, firms are faced with intensifying competition locally and globally, and fast changes in customers and technologies. In this environment it is vital that small and medium enterprises (SMEs) are equipped with appropriate and modern financial and management accounting practices in order for them to survive and remain profitable. One of the factors that determine the performance of a business organization is effective use of financial and management accounting reports. However, thus far very little published evidence on accounting practices among SMEs in Malaysia is found. This study aims to examine the financial and management accounting practices among SMEs in Malaysia and to investigate perceived usefulness of accounting reports for decision making. A survey was carried out using the SMEs in manufacturing listed by SMIDEC, as the sampling frame. A total of 76 usable questionnaires were used for the final data analysis. The findings from the survey provide pertinent and useful insights into the current financial and management accounting practices and the level of perceived usefulness of the accounting reports among SMEs. The results of the study indicate that a majority of the firms surveyed prepare their financial and management accounting reports on a monthly basis. With regards to the purpose of financial accounting reports, the results show that preparing tax returns rank first, followed by providing information to shareholders, and providing information to government agencies. Management accounting reports provide the most useful information for planning and control, followed by product pricing and lastly, employee performance evaluation. Financial accounting reports were perceived to be more useful than management accounting reports. Among the financial accounting reports, profit and loss statement was considered as most useful, followed by cash flow and balance sheet. Among the management accounting reports, production report was rated highest in terms of usefulness, followed by budget and variance analysis.
\end{abstract}

Keywords: SMEs, accounting practices, financial accounting reports, management accounting reports.

\section{Introduction}

Small and medium enterprises (SMEs) play an important role in the development of the Malaysian economy through their significant contributions in terms of manufacturing output and job creation. They represent more than 80 percent of manufacturing firms in Malaysia and provided more than 30 percent of total employment in the industry. SMEs' contribution

Corresponding author: Dr Che Ruhana Isa, Associate Professor (cruhana@um.edu.my), co-authored Dr Zakiah Saleh, Senior Lecturer (zakiahs@um.edu.my), Noor Sharoja Sapiei, Lecturer (noorsharoja@um.edu.my). All authors from Faculty of Business and Accountancy, University of Malaya.

Acknowledgement: This study is funded by the Center of Economic Development and Ethnic Relations (CEDER), University of Malaya. 
is crucial in Malaysia's quest to be an industrialized country through the strengthening of both the forward and backward industrial linkages. SMEs complement the activities of the larger scale industries through the integration into the mainstream of industrial development by providing the industries with critical parts and components as well as expanding into international markets. SME represents a company having an annual sales turnover of less than RM25 million and not more than 150 full-time employees.

Escalation in competition as a result of globalization and trade liberalizations has changed the business environment internationally as well as on the domestic front. The rapid pace of technological advancements in the manufacturing as well as in information and communication technologies (ICT) has transformed the business environment to become much more complex and challenging. In order to survive and remain competitive, SMEs must respond to these changes in a timely manner. Unfortunately, many SMEs are unable to sustain their positions in the long term. Among the factors that are argued to contribute to the failure of SMEs is a lack of proper financial management and cost control such as inadequate or inaccurate financial records; inability to manage fluctuating costs and prices effectively; undercapitalization; poor stock and credit controls; lack of financial planning and unproductive use of assets; which are crucial in determining business performance. Sound financial management requires a good and reliable source of information, which could be obtained from adequate, timely, and effective financial reporting, as well as management accounting and control practices.

Despite the importance of financial reporting, management accounting and control practices, it is unfortunate to find that these practices are often inadequate and lacking among SMEs. Except for yearly taxation returns and some form of profit and loss statements, other statements such as balance sheet, cash flow statement, fund statement, production report, variance report, etc., are infrequently used. This rather limited usage of financial and management accounting reports could be attributed to SMEs' inability to employ professional managers with functional specialization, especially in the financial area due to their limited financial resources. Without adequate, effective and timely financial reports and analysis, SMEs are losing out on the benefits from practices such as improved monitoring of financial health and progress, improved ability to anticipate fortunes or failures, better assessment of financial risks and greater ease in financial planning and control. Most importantly, in the context of SMEs requiring extra capital to grow, regular financial reports can provide indications on their ability to produce steady cash flows and to service debt. While it has been established that the use of appropriate financial reporting and management accounting practices could be one of the determinants of company survival, particularly SMEs (Gorton, 1999; McMahon \& Holmes, 1991), not much research has been carried out in this area in Malaysia.

There has been very limited research focusing on accounting practices of SMEs in Malaysia. Studies on management accounting practices that have been carried out so far (Tho, et al., 1998; Ahmad et al., 2003; Sulaiman, et al., 2005) did not focus specifically on SMEs but their results provide information on management practices among Malaysian manufacturers. Sulaiman et al. (2004), in their review of management accounting practices in selected Asian countries, concluded that traditional management accounting techniques continued to be widely used by companies in Malaysia, Singapore, China and India. For example, Sulaiman et al. (2004) cited a study by Abdul Rahman and others in 1998, which found that budgets were used by $98 \%$ of Malaysian manufacturing firms. A similar result was found by Sulaiman et al. (2002) who surveyed companies in the industrial and consumer products sectors. A review of the relevant literature shows that there is a gap in the studies relating to SME accounting practices in Malaysia. 


\subsection{Objectives and Significance of the Research}

In view of the lack of evidence on accounting practices among SMEs in Malaysia, this study aims to examine financial and management accounting practices among SMEs in Malaysia and to assess the usefulness of financial and management accounting reports. Specifically, the objectives of the study are as follows:

i. To examine financial and management accounting practices among SMEs.

ii. To investigate the level of perceived usefulness of financial and management accounting reports for decision making.

The findings of this study provide information on the extent of financial and management accounting practices as well as perceived usefulness of accounting reports for decision making. Based on these findings, further research can be carried out to investigate whether accounting practices and performance are related. The information on SMEs' accounting practices and performance will provide invaluable insights and input, especially to the government in assessing whether further assistance could be provided to SMEs.

\section{Literature Review}

There has been very limited research focusing on accounting practices of SMEs in Malaysia. Most published studies look at SMEs in Australia, the U.K. and North America. In Australia, there have been a large number of empirical studies conducted on SMEs such as McMahon and Davies (1994), McMahon (1998, 2001) and others. These studies investigate the types of financial reports produced by SMEs, the frequency of their preparation, and their perceived usefulness for management purposes. The findings indicate that financial reports for SMEs are prepared predominantly by external accountants at annual intervals, and they normally comprise just the balance sheet and the profit and loss statement. The content and presentation of financial reports appear to be greatly influenced by taxation and corporate statutory reporting requirements.

Based on a literature review on financial management practices of SMEs in North America, McMahon and Holmes (1991, p. 27) concluded that "...the state of knowledge about financial management and the exercise of financial controls and techniques remains inadequate in small businesses". Gorton (1999) cited a study by Nayak and Greenfield (1994) on 200 manufacturing firms employing less than ten people in the U.K., which provides evidence that only one third of businesses formally monitored profits and applied any form of budgeting. A study by Hopper et al. (1999) found similarities between costing systems used by SMEs and larger companies. The costing systems and cost management practices used by SMEs were mainly for product costing and budget and less emphasis for decision making or performance evaluation. They also found that a sophisticated detailed process of cost management was commonly used for engineering and quality control.

In a study involving more than 1,000 SMEs in Australia, McMahon (1998) found that the majority of the respondents $(85.7 \%)$ have a computer-based in-house general ledger accounting system. Larger enterprises tend to statistically use more computer-based general ledger accounting systems compared to smaller enterprises. In addition, 64.6 percent of the companies surveyed also indicate that they have an in-house computer-based budgeting system.

Collis and Jarvis (2002) examined private limited companies in the U.K. Their findings show that 57 percent of the respondents had a computerised accounting system and 25 percent had a partly computerised system suggesting a moderate level of sophistication of accounting system. Similarly Gorton (1999) found that SMEs that are concerned with procedural controls activities and use financial plans as a part of their preparation for start up are more likely to employ a computerized accounting system. In addition to their internal 
accounting staff, SMEs often employ outside professionals to provide accounting advice. It has been found that the most frequent form of outsourced accounting services are for taxation purposes and preparation of accounting reports (e.g., Collis \& Jarvis, 2002; McMahon, 1998).

Studies were conducted in various countries to examine the usefulness of accounting reports within the context of SMEs, for example; McMahon $(1998,2001)$ in Australia, Collis and Jarvis (2002), Gorton (1999) and Nayak and Greenfield (1994) in the U.K.; and Hopper et al. (1999) on small and medium sized Japanese companies. These studies found evidence that financial reports are not considered particularly useful for decision making purposes by SME owner-managers. These studies also found that there is limited usage of financial and management accounting reports by SMEs. In addition, it has been argued that accounting reports produced by SMEs are usually limited to a few types of simple reports comprising mainly profit and loss account and balance sheet. Using a postal questionnaire to small private limited companies in the U.K., Collis and Jarvis (2002) found that 82 percent of the companies use monthly or quarterly management accounts, 87 percent of the companies prepare profit and loss statements and 78 percent prepare a balance sheet. On the other hand, Collis and Jarvis (2002) argued that SMEs consider the most frequently used sources of information are the periodic management accounts, cash flow information and bank statements, and to a lesser extent, budgets, the state of order book and the additional annual accounts.

\section{Research Methodology}

Data was collected using a postal questionnaire survey. Despite the approach's limitations, such as non-response, postal questionnaire permits data to be collected from a representative sample across many industries and geographical regions (Hussey and Hussey, 1997). The sample was selected from the Small and Medium Industries Development Corporation (SMIDEC) directory (2005), which was available on the agency's website. A total of 500 respondents were randomly selected from the database. The questionnaires were mailed to the respondents and a total of 76 useable questionnaires were obtained and used for the final analysis, representing a response rate of 15 percent. For the purpose of data analysis from the survey, standard statistical techniques using SPSS, including frequencies and descriptive analysis, were used. To examine non-response bias, an independent sample $t$-test was conducted to detect any significant difference in the responses between early and late respondents and the results did not show any significant difference.

This study is exploratory in nature with similarities in terms of objectives with the study by McMahon (1998). Subsequently, the questionnaire used in this study was designed based on McMahon (1998). McMahon's study covers enterprise characteristics and performance, and financial management characteristics and practices. However, since the focus of this study is on financial and management accounting practices, only relevant questions were extracted. A pilot test was conducted to examine the validity and relevance of the questions. The questionnaire was sent to the selected SMEs and relevant changes were made based on the comments received.

\section{Results}

This section provides descriptive statistics on the profile of the sample firms and the respondents, as well as the results of the statistical analysis related to financial accounting and management accounting practices among SMEs, and the purpose and perceived usefulness of accounting reports for decision making. 


\subsection{Profile of Sample Firms and Respondents}

Table 1 shows the frequencies related to the characteristics of the sample firms. It shows that firms that participated in the survey are relatively 'young' as less than 40 percent have been in business for more than 15 years. In terms of the number of employees, the majority of the firms, almost 90 percent, have 150 or less, full time employees, which fits them in the small and medium firms' category. As for firm ownership, 34 percent of the firms are owned by bumiputra, while 46 percent are owned by non-bumiputra. 49 percent are local and only 8 percent are foreign owned. Firms from two industries, food, beverage and tobacco, and electrical and electronics machinery and appliances, make up the largest group of respondents with 21 and 16 percent of participation.

Table 2 displays the profile of the respondents. More than 50 percent of the respondents are directors and managers, while 27.7 and 9.2 percent are executives and accountants, respectively. The majority $(70.3 \%)$ of the respondents have worked for the company for more than three years and almost 80 percent have a diploma or higher academic qualification. In addition, more than 90 percent indicated involvement in decision making. From the profile of the respondents, it can be assumed that most of them have adequate work experience and knowledge about the operations of their firms, and, thus, are able to provide reliable information about their firms. 
Table 1: Profile of Sample Firms

\begin{tabular}{|c|c|c|}
\hline Organizational Information & Frequency & Percent \\
\hline \multicolumn{3}{|l|}{ Years of operation: } \\
\hline 1 to 5 years & 6 & 8.3 \\
\hline 6 to 10 years & 21 & 29.2 \\
\hline 11 to 15 years & 17 & 23.6 \\
\hline More than 15 years & 28 & 38.9 \\
\hline Total & 72 & 100.0 \\
\hline \multicolumn{3}{|l|}{ Number of full time employees: } \\
\hline 1 to 50 employees & 47 & 65.3 \\
\hline 51 to 100 employees & 10 & 13.9 \\
\hline 101 to 150 employees & 9 & 12.5 \\
\hline 151 to 200 employees & 3 & 4.2 \\
\hline More than 200 employees & 3 & 4.2 \\
\hline Total & 72 & 100.0 \\
\hline \multicolumn{3}{|l|}{$\begin{array}{l}\text { Firm ownership (firms may belong to more than one categories): } \\
\text { 1. Bumiputra }\end{array}$} \\
\hline 2. Non-bumiputra & 22 & $34.0 *$ \\
\hline 3. Local owned & 35 & 46.0 \\
\hline 4. Foreign owned & 37 & 49.0 \\
\hline *Percentage id based on the total number of firms, 76 . & 6 & 8.0 \\
\hline \multicolumn{3}{|l|}{ Type of Industry: } \\
\hline 1. Electrical and electronics machinery and appliances & 12 & 16.0 \\
\hline 2. Food, beverage and tobacco & 16 & 21.3 \\
\hline 3. Textiles, clothing and footwear & 3 & 4.0 \\
\hline 4. Transport and automotive & 1 & 1.3 \\
\hline 5. Wood and timber products/Furniture manufacturing & 3 & 4.0 \\
\hline 6. Metallurgical or metal goods & 7 & 9.3 \\
\hline 7. Others & 33 & 44.0 \\
\hline Total & 75 & 100.0 \\
\hline \multicolumn{3}{|l|}{ Annual Turnover: } \\
\hline$<$ RM10 million & 41 & 55.4 \\
\hline RM10 million - RM25 & 21 & 28.4 \\
\hline$>$ RM25 million & 12 & 16.2 \\
\hline Total & 74 & 100.0 \\
\hline \multicolumn{3}{|l|}{ Paid up capital: } \\
\hline$<$ RM500,000 & 25 & 35.2 \\
\hline RM501,000 - RM2.5 million & 27 & 38.0 \\
\hline$>$ RM2.5 million & 19 & 26.8 \\
\hline Total & 71 & 100.0 \\
\hline
\end{tabular}


Table 2: Profile of Respondents

\begin{tabular}{lll}
\hline Respondents Information & Frequency & Percent \\
\hline Position: & & \\
Director & 19 & 29.2 \\
Manager & 20 & 30.8 \\
Executive & 18 & 27.7 \\
Accountant & 6 & 9.2 \\
$\quad$ Other & 2 & 3.1 \\
Total & 65 & 100.0 \\
Experience: & & \\
$\quad$ Less than 1 year & 4 & 5.4 \\
$\quad$ 1-3 years & 18 & 24.3 \\
$\quad$ More than 3 years & 52 & 70.3 \\
Total & 74 & 100.0 \\
Academic Qualifications: & & \\
$\quad$ SPM & 7 & 9.7 \\
$\quad$ STPM & 1 & 1.4 \\
$\quad$ Diploma & 18 & 25.0 \\
$\quad$ Bachelor & 35 & 48.6 \\
$\quad$ Masters & 4 & 5.6 \\
$\quad$ Others & 7 & 9.7 \\
Total & 72 & 100.0 \\
Involvement in accounting decision making: & & \\
$\quad$ Yes & 66 & 91.7 \\
$\quad$ No & 6 & 8.3 \\
Total & 72 & 100.0 \\
\hline
\end{tabular}

\subsection{Financial and Management Accounting Practices}

\subsubsection{Financial Accounting Practices}

The results in Table 3 show that all respondents (100 percent) prepare a balance sheet and profit and loss account. The finding is similar with findings of previous studies in Australia (McMahon, 1998), which suggest that financial reports of SMEs normally comprise a balance sheet and profit and loss account. Apart from the main financial statements, the respondents also prepared cash flow statements, fixed asset record, tax returns and inventory analysis.

In terms of the frequency of report preparation, more than half of the respondents indicate that they prepare these reports on a monthly basis. It might be a reflection of a conventional monthly accounting cycle on which general ledger systems are usually based. Another explanation might be due to a typical monthly business pattern. Annual financial reporting comes second, followed by quarterly and semi-annually.

Concerning the individual financial accounting report, as reflected by the above statistic, out of 76 respondents, 56 SMEs or 69.7 percent of the total respondents prepare a monthly profit and loss statement, followed closely by balance sheet with 60.5 percent. The profit and loss statement allows the management to measure the profitability of their business undertakings while the balance sheet allows management to monitor their net asset balances.

In addition, consistent with previous research (e.g. Mc Mahon, 1998), which suggests that cash flow information is critical to the success and survival of SMEs, 58.7 percent of the respondents prepare a monthly cash flow statement. With regard to annual accounting reports, balance sheet takes the lead with 22.4 percent or 17 SMEs prepared balance sheets annually. Requirements of accounting standards for companies to prepare annual financial statements might be the reason for the results. Cash flow statement is second place with 20 percent which might show that SMEs are more concerned with cash conditions and financing requirements compared to profit and loss statement, which comes third with only 14.5 
percent of respondents preparing it. From the study, there was little evidence that SMEs were producing reports on a quarterly or semi-annually basis. For example, only 7.9 percent of respondents stated that they produce a balance sheet quarterly, and even fewer $(5.3 \%)$ stated that they produce a balance sheet semi-annually. For profit and loss statement, a slightly higher percentage $(9.2 \%)$ prepared the report quarterly but only 3.9 percent prepared semiannually. Surprisingly, only 1 percent of the SMEs prepared a quarterly and semi-annual cash flow statement.

Table 3: Frequency of Financial Accounting Reports

\begin{tabular}{|c|c|c|c|c|c|c|c|}
\hline \multirow{3}{*}{$\begin{array}{l}\text { Financial } \\
\text { Accounting } \\
\text { Reports }\end{array}$} & \multicolumn{7}{|c|}{ Frequency of Reporting } \\
\hline & Weekly & Monthly & Quarterly & Semi- & Annually & Other & Total \\
\hline & $\mathrm{N}(\%)$ & $\mathrm{N}(\%)$ & $\mathrm{N}(\%)$ & $\begin{array}{l}\text { annually } \\
\mathrm{N}(\%)\end{array}$ & $\mathrm{N}(\%)$ & $\mathrm{N}(\%)$ & $\mathrm{N}(\%)$ \\
\hline Balance & $3(3.9)$ & $46(60.5)$ & $6(7.9)$ & $4(5.3)$ & $17(22.4)$ & - & $76(100)$ \\
\hline Sheet & & & & & & & \\
\hline $\begin{array}{l}\text { Profit \& } \\
\text { Loss }\end{array}$ & $2(2.6)$ & $53(69.7)$ & $7(9.2)$ & $3(3.9)$ & $11(14.5)$ & - & $76(100)$ \\
\hline Cash Flow & $12(16.9)$ & 44 (58.7) & $1(1.3)$ & $1(1.3)$ & $15(20.0)$ & - & 75 (98.7) \\
\hline Tax & - & $5(6.7)$ & $6(8.0)$ & $6(8.0)$ & $58(77.3)$ & $2(2.7)$ & 75 (98.7) \\
\hline Returns & & & & & & & \\
\hline $\begin{array}{l}\text { Inventory } \\
\text { Analysis }\end{array}$ & $7(9.2)$ & $45(61.6)$ & $3(4.1)$ & $3(4.1)$ & $14(19.2)$ & $1(1.4)$ & $73(96.1)$ \\
\hline $\begin{array}{l}\text { Fixed Asset } \\
\text { Record }\end{array}$ & $1(1.3)$ & $30(39.5)$ & $2(2.6)$ & $8(10.5)$ & $34(44.7)$ & $1(1.3)$ & $76(100)$ \\
\hline
\end{tabular}

Notes: $\mathrm{N}=$ Number of firms

Apart from the main financial accounting reports, tax returns, inventory analysis and fixed asset record are also prepared by the SMEs but to a lesser extent of frequency. Tax returns are mainly produced annually with 77.3 percent, which might reflect the statutory requirements of the Inland Revenue Board for each year of assessment. Fixed assets record is also prepared annually (44.7\%) and monthly (39.5\%). Inventory analysis, in contrast, is mainly produced monthly (61.65), only under 20 percent annually. This might be reflective of the new inventory system requirement, which requires companies to analyse their inventory in a shorter time span. The findings on the frequency of reporting are similar to the Australian SME research by McMahon (1998) where the frequency of reports for financial accounting statement is overwhelmingly 'monthly'.

\subsubsection{Management Accounting Practices}

The management accounting reports studied include budgets and different types of budget, variance analysis, production cost statement, cost volume profit (CVP) analysis and benchmarking report. The findings, as displayed in Table 4, show that among the management accounting reports, the majority of the respondents $(92.1 \%)$ prepared budgets, followed by production cost statement $(82.9 \%)$, variance analysis $(80.3 \%)$, CVP analysis (73.7\%) and benchmarking reporting (57.9\%). Among the different types budgets, cash budget is the most frequently prepared $(93.4 \%)$, followed by sales budget $(92.1 \%)$, expenses budget $(86.8 \%)$ and lastly production budget $(85.5 \%)$.

The least prepared management accounting report is the benchmarking report. One plausible explanation for this is the difficulty in finding appropriate firms to benchmark, since a large number of SMEs operate in niche markets. Another reason might be that most SMEs only produce abbreviated accounts, so a comparison might be difficult.

The frequency of management accounting reporting is quite similar to those of financial accounting reports. With the exception of the budget and benchmarking report, most 
respondents predominantly prepared monthly reporting, followed by annual reporting. Over 60 percent of the respondents stated that they prepared a production cost statement on a monthly basis. Slightly more than half $(52.5 \%)$ of the respondents prepares variance analysis on a monthly basis and 50 percent of the respondents also prepare a monthly Cost Volume Profit (CVP) analysis.

Table 4: Frequency of Management Accounting Reports

\begin{tabular}{|c|c|c|c|c|c|c|c|}
\hline \multirow[b]{2}{*}{$\begin{array}{l}\text { Mgmt } \\
\text { Accounting } \\
\text { Reports }\end{array}$} & \multicolumn{7}{|c|}{ Frequency of Reporting } \\
\hline & $\begin{array}{l}\text { Weekly } \\
\mathrm{N}(\%)\end{array}$ & $\begin{array}{l}\text { Monthly } \\
\text { N (\%) }\end{array}$ & $\begin{array}{l}\text { Quarterly } \\
\mathrm{N}(\%)\end{array}$ & $\begin{array}{l}\text { Semi- } \\
\text { annually } \\
\mathrm{N}(\%)\end{array}$ & $\begin{array}{l}\text { Annually } \\
\mathrm{N}(\%)\end{array}$ & $\begin{array}{l}\text { Other } \\
\mathrm{N}(\%)\end{array}$ & $\begin{array}{l}\text { Total } \\
\mathrm{N}(\%)\end{array}$ \\
\hline Budget & 2.(2.9) & $21(30)$ & $6(8.6)$ & $6(8.6)$ & 34 (48.6) & $1(1.4)$ & 70 (92.1) \\
\hline Cash Budget & $9(12.7)$ & $24(33.8)$ & $8(11.3)$ & $6(8.5)$ & $22(31)$ & $2(2.8)$ & 71 (93.4) \\
\hline Sales Budget & $3(4.3)$ & $29(41.4)$ & $13(18.6)$ & $6(8.6)$ & $17(24.3)$ & $2(2.9)$ & $70(92.1)$ \\
\hline $\begin{array}{l}\text { Production } \\
\text { Budget }\end{array}$ & $8(12.3)$ & $26(40)$ & $11(16.9)$ & $5(7.7)$ & $13(20$ & $2(3.1)$ & $65(85.5)$ \\
\hline $\begin{array}{l}\text { Expenses } \\
\text { Budget }\end{array}$ & 8.(11.9) & $24(35.8)$ & $10(14.9)$ & $4(6)$ & $20(29.9)$ & $1(1.5)$ & $66(86.8)$ \\
\hline $\begin{array}{l}\text { Variance } \\
\text { Analysis }\end{array}$ & - & $32(52.5)$ & $9(14.8)$ & $3(4.9)$ & $15(24.6)$ & $2(3.3)$ & $61(80.3)$ \\
\hline $\begin{array}{l}\text { Production } \\
\text { Cost } \\
\text { Statement }\end{array}$ & $2(3.2)$ & $40(63.5)$ & $7(11.1)$ & $5(7.9)$ & $8(12.7)$ & $1(1.6)$ & $63(82.9)$ \\
\hline CVP Analysis & $1(1.8)$ & $28(50)$ & 10 (17.9) & $5(8.9)$ & $11(19.6)$ & $1(1.8)$ & $56(73.7)$ \\
\hline $\begin{array}{l}\text { Benchmarking } \\
\text { Report }\end{array}$ & $1(2.3)$ & $9(20.5)$ & $6(13.6)$ & $8(18.2)$ & $18(40.9)$ & $2(4.5)$ & $44(57.9)$ \\
\hline
\end{tabular}

Notes: $\mathrm{N}=$ Number of firms

With regard to annual reporting, only 24.6 percent of the respondents prepared a variance analysis report, followed by CVP analysis (19.6\%) and production cost statement (7.6\%). In contrast, for budget report, nearly half (48.6\%) of the respondents prepared the report on an annual basis, and only 30 percent on a monthly basis. Similarly, 40.9 percent of the respondents prepared an annual benchmarking report and 9 percent prepared the report on a monthly basis. Again, similar to the financial accounting reporting, quarterly and semiannually reporting for management accounting reports is not so common among SMEs. It can be concluded that most SMEs produce their financial and management accounting reports on a monthly and annual basis.

\subsubsection{Preparation of Reports}

In preparing financial reports, the majority of the respondents use accrual accounting as the basis. As shown in Table 5, 83 percent adopted the accrual basis while only 9 percent adopted the modified basis.

Table 5: Accounting Basis

\begin{tabular}{lll}
\hline Basis of Accounting & Frequency & \\
\cline { 2 - 3 } & $\mathrm{N}$ & Percentage \\
\hline Accrual & 63 & 83 \\
Modified cash & 4 & 5 \\
Modified accrual & 3 & 4 \\
No response & 6 & 8 \\
\hline
\end{tabular}


Collis and Jarvis (2002) stated that SMEs show a degree of sophistication in the preparation of reports through the use of accounting software packages and by outsourcing external accountants for the purpose. Collis and Jarvis suggested that SMEs should utilize computerized accounting systems to meet management's information needs. Table 6 shows that out of 76 respondents, 95 percent indicate the use of a computerized system in the preparation of financial and management accounting reports. Some of them use both computerized and manual systems. Out of those that indicated the computerized system in use, the majority (87\%) purchased standard (or off-the-shelf) accounting software packages, while 13 percent of them had a tailored computer-based accounting system. The results show that the majority of Malaysian SMEs use a computerized accounting system, thus, managers have better access to financial information.

Table 6: Preparation of Reports

\begin{tabular}{lllll}
\hline $\begin{array}{l}\text { Preparation of financial and management accounting } \\
\text { reports }\end{array}$ & YES & \multicolumn{3}{c}{ NO } \\
\cline { 2 - 5 } & $\mathrm{N}$ & $\%$ & $\mathrm{~N}$ & $\%$ \\
\hline $\begin{array}{l}\text { Computerized * } \\
\text { Standard (off the-shelf) }\end{array}$ & 46 & 61 & 30 & 40 \\
$\quad$ Tailored & 7 & 9 & 69 & 91 \\
Manual & 4 & 5 & 72 & 95 \\
Both & $35^{* *}$ & 46 & 41 & 54 \\
\hline Note: $* \quad$ Some of the respondents who indicated their computerized system also indicated \\
$\quad$ that they utilized both computerized and manual systems \\
$\quad$ Not mutually exclusive
\end{tabular}

As shown in Table 7, the findings also indicate that slightly more than half of the respondents (59\% or 45 out of 76 respondents) engaged the service of external accountants in preparing the financial and management accounting reports. Out of this, 84 percent engaged accountants with a professional qualification. In addition to the outsource accountants to prepare financial and management accounting reports, the respondents also indicated that they employed accounting personnel.

Table 7: Outsourced Preparers of Reports

\begin{tabular}{lll}
\hline Outsourced Accountants & Frequency & \\
\cline { 2 - 3 } & $\mathrm{N}$ & Percentage \\
\hline Diploma in Accounting & 3 & 7 \\
Degree in Accounting & 4 & 9 \\
Professional Accountants & 38 & 84 \\
Total & 45 & 100 \\
\hline
\end{tabular}

Referring to Table 8, only three of the respondents employ more than three accounting staff. The rest of the respondents had between one and three accounting personnel. In terms of qualifications, 65 percent of the respondents employed staff with a diploma in accounting, 37 percent with a degree in accounting, and 28 percent with a professional qualification.

Table 8: Internal Preparers of Reports

\begin{tabular}{llll}
\hline Internal Accounting Staff & \multicolumn{2}{l}{ Number of staff involved* } \\
\cline { 2 - 4 } & $1-3$ & $>3$ & Total \\
\hline Diploma in Accounting & $41(62 \%)$ & $2(3 \%)$ & $49(65 \%)$ \\
Degree in Accounting & $27(35 \%)$ & $1(2 \%)$ & $28(37 \%)$ \\
Professional Accountants & $21(28 \%)$ & - & $21(28 \%)$ \\
Other & $21(28 \%)$ & - & $21(28 \%)$ \\
\hline
\end{tabular}

Notes: * Answers are not mutually exclusive 


\subsection{Purposes and Perceived Usefulness of Accounting Reports 4.3.1. Purposes of Accounting Reports}

Table 9 displays the purposes of financial and management accounting reports as perceived by the respondents. A ranking for the purposes was developed based on the frequency obtained for each category. In terms of frequency, Table 9 shows that 'prepare tax return' was the highest $(85.3 \%$ ) ranked purpose of financial accounting reports. 'Provide information to shareholders' is the second highest $(69.3 \%)$ ranked purpose, followed by 'provide information to relevant government agencies' (68.0\%), 'provide information to creditors' (61.3\%), and 'management decision making for planning and control' (44\%). The lowest ranked purposes of financial accounting reports are 'managers/employees performance evaluation' (25.3\%) and 'product pricing' $(26.7 \%)$.

In contrast, the table shows that the top three ranked purposes of management accounting reports are 'management decision making, planning and control' (78.7\%), followed by 'product pricing' (77.7\%) and 'managers/employees performance evaluation' (73.3\%). 'Product costing' was ranked fourth (72\%) in terms of purposes of management accounting reports, followed by 'firm performance evaluation' (68\%) and 'inventory valuation' $(61.3 \%)$. The lowest ranked purposes of management accounting reports are 'prepare tax return' (20\%) and 'provide information to creditors' $(28 \%)$. The results are consistent with our expectation that financial accounting reports are used mainly for external purposes including tax return, shareholders, government agencies and creditors. On the other hand, management accounting reports are used mainly for internal purposes, which include planning and control, pricing decisions and performance evaluation.

Table 9: Purpose(s) of Financial Accounting Reports

\begin{tabular}{|c|c|c|c|c|c|c|}
\hline \multirow[t]{2}{*}{ Purposes } & \multicolumn{3}{|c|}{ Financial Accounting Reports } & \multicolumn{3}{|c|}{ Management Accounting Reports } \\
\hline & $\begin{array}{l}\text { YES } \\
\mathrm{N}(\%)\end{array}$ & $\begin{array}{l}\mathrm{NO} \\
\mathrm{N}(\%)\end{array}$ & Rank & $\begin{array}{l}\text { YES } \\
\mathrm{N}(\%)\end{array}$ & $\begin{array}{l}\mathrm{NO} \\
\mathrm{N}(\%)\end{array}$ & Rank \\
\hline Prepare tax return & $\begin{array}{l}64 \\
(85.3 \%)\end{array}$ & $\begin{array}{l}11 \\
(14.7 \%)\end{array}$ & 1 & $\begin{array}{l}15 \\
(20 \%)\end{array}$ & $\begin{array}{l}60 \\
(80 \%)\end{array}$ & 10 \\
\hline $\begin{array}{l}\text { Provide information to } \\
\text { shareholders }\end{array}$ & $\begin{array}{l}52 \\
(69.3 \%)\end{array}$ & $\begin{array}{l}23 \\
(30.7)\end{array}$ & 2 & $\begin{array}{l}32 \\
(42.7 \%)\end{array}$ & $\begin{array}{l}43 \\
(57.3 \%)\end{array}$ & 7 \\
\hline $\begin{array}{l}\text { Provide information to relevant } \\
\text { government agencies }\end{array}$ & $\begin{array}{l}51 \\
(68.0 \%)\end{array}$ & $\begin{array}{l}24 \\
(32.0 \%)\end{array}$ & 3 & $\begin{array}{l}23 \\
(30.7 \%)\end{array}$ & $\begin{array}{l}52 \\
(69.3 \%)\end{array}$ & 8 \\
\hline $\begin{array}{l}\text { Provide information to } \\
\text { creditors }\end{array}$ & $\begin{array}{l}46 \\
(61.3 \%)\end{array}$ & $\begin{array}{l}29 \\
(38.7 \%)\end{array}$ & 4 & $\begin{array}{l}21 \\
(28 \%)\end{array}$ & $\begin{array}{l}54 \\
(72 \%)\end{array}$ & 9 \\
\hline $\begin{array}{l}\text { Management decision making } \\
\text { for planning and control }\end{array}$ & $\begin{array}{l}33 \\
(44 \%)\end{array}$ & $\begin{array}{l}42 \\
(56 \%)\end{array}$ & 5 & $\begin{array}{l}59 \\
(78.7 \%)\end{array}$ & $\begin{array}{l}16 \\
(21.3 \%)\end{array}$ & 1 \\
\hline Firm performance evaluation & 31 & $\begin{array}{l}44 \\
(58.7 \%)\end{array}$ & 6 & 51 & $\begin{array}{l}24 \\
(32 \%)\end{array}$ & 5 \\
\hline Inventory valuation & $\begin{array}{l}30 \\
(40.0 \%)\end{array}$ & $\begin{array}{l}45 \\
(60.0 \%)\end{array}$ & 7 & $\begin{array}{l}46 \\
(61.3 \%)\end{array}$ & $\begin{array}{l}29 \\
(38.2 \%)\end{array}$ & 6 \\
\hline Product costing & $\begin{array}{l}24 \\
(32.0 \%)\end{array}$ & $\begin{array}{l}51 \\
(68.0 \%)\end{array}$ & 8 & $\begin{array}{l}54 \\
(72 \%)\end{array}$ & $\begin{array}{l}21 \\
(28 \%)\end{array}$ & 4 \\
\hline Product pricing & $\begin{array}{l}20 \\
(26.7 \%)\end{array}$ & $\begin{array}{l}55 \\
(73.3 \%)\end{array}$ & 9 & $\begin{array}{l}58 \\
(77.3)\end{array}$ & $\begin{array}{l}17 \\
(22.7 \%)\end{array}$ & 2 \\
\hline $\begin{array}{l}\text { Managers/employees } \\
\text { performance evaluation }\end{array}$ & $\begin{array}{l}19 \\
(25.3 \%)\end{array}$ & $\begin{array}{l}56 \\
(74.7 \%)\end{array}$ & 10 & $\begin{array}{l}55 \\
(73.3 \%)\end{array}$ & $\begin{array}{l}20 \\
(26.7 \%)\end{array}$ & 3 \\
\hline
\end{tabular}

Notes: $\mathrm{N}=$ Number of firms 


\subsubsection{Perceived Usefulness of Accounting Reports}

In measuring perceived usefulness of accounting reports, the respondents were asked to rate the level of usefulness of accounting reports for decision making on a Likert scale of 1 (least useful) to 5 (most useful). Overall, most respondents considered financial accounting reports (mean=4.11) to be more useful than management accounting reports (mean=3.55) as indicated in Table 10. When asked to rate on the usefulness of each report, the profit and loss statement was ranked first (mean=4.43), followed by the cash flow statement (mean=4.04), and the balance sheet in third place $($ mean=3.87). On the other hand, management accounting reports comprising production report (mean=3.69), budget (mean=3.63) and variance analysis (mean $=3.35$ ) were considered as least important occupying the fourth, fifth and last ranking, respectively. The fact that profit and loss account and cash flow statements were ranked the highest in terms of usefulness (mean values above 4.0) indicates the importance placed on profitability and controlling cash by SMEs, which previous research (Birley \& Niktari, 1995; Jarvis et al., 2000) suggests is critical to the success and survival of a small business.

Table 10: Usefulness of Financial and Management Accounting Reports

\begin{tabular}{llll}
\hline Accounting Reports & Mean & Std. Deviation & Rank \\
\hline Overall Usefulness: & & & \\
$\quad$ Financial Accounting Reports & 4.11 & 0.92 & 1 \\
$\quad$ Management Accounting Reports & 3.55 & 0.94 & 2 \\
Usefulness of Each Report: & & & \\
$\quad$ Profit \& Loss & 4.43 & 1.06 & 1 \\
Cash Flow & 4.04 & 1.25 & 2 \\
Balance Sheet & 3.87 & 1.00 & 3 \\
Production report Budget & 3.69 & 1.20 & 4 \\
Budget & 3.63 & 0.97 & 5 \\
Variance analysis & 3.35 & 1.19 & 6 \\
\hline
\end{tabular}

Notes: Cronbach's alpha $=0.77$, Scale: 1 (least useful) to 5 (most useful)

\section{Summary and Conclusion}

Small and medium enterprises (SMEs) are going to play a greater role in the Malaysian economy. However, little is known whether SMEs are ready to face the challenges from increasing uncertainties and competition in the global market, particularly in terms of their application of adequate financial and management accounting practices for decision making. This study attempts to find out the extent of financial and management accounting practices employed by SMEs and to investigate the perceived usefulness of accounting reports for decision making. The results provide evidence that the majority of companies prepare financial and management accounting reports such as profit and loss, balance sheet, and cash flow statements on a regular basis and there is adequate evidence to suggest a high use of computerised accounting systems. In terms of usefulness of accounting reports, financial accounting reports are considered to be more useful than management accounting reports.

The results of the study, however, are limited in several ways. First, the study is associated with the usual limitations of cross-sectional survey research, namely data collected at a single point of time. Second, this study covers only a small number of manufacturing firms. Hence, the findings of the study might limit their generalisability. Future research can be conducted to explore further accounting practices among SMEs in other sectors such as the service sector. In addition, studies can also be carried out to investigate the relationship between accounting practices and performance. Other approaches to research such as case study and in-depth interviews can be employed to gain insights into the contextual factors affecting accounting practices in SMEs. Future research can also be undertaken to identify 
problems and areas of improvement, which can be used by the relevant government agencies to formulate policies to ensure the survival of SMEs in Malaysia.

\section{References}

Ahmad, Nik Nazli; Sulaiman, M., and Alwi, M.N. (2003). Are budgets useful? A survey of Malaysian Companies, Managerial Auditing Journal, 18 (9), pp. 717-72.

Birley, S. and Niktari, N. (1995). The Failure of Owner-Managed Businesses: The Diagnosis of Accountants and Bankers, ICAEW, London.

Collis, J. and Jarvis, R. (2002). Financial information and the management of small private companies. Journal of Small Business and Enterprise Development, 9(2), pp. 100-10.

Gorton, M., (1999). Use of financial management techniques in the U.K. - based small and medium sized enterprises: empirical research findings. Journal of Financial Management \& Analysis, Jan-Jun, 12 (1), pp. 56-64.

Hopper, T., Koga, T. and Goto, J. (1999). Cost accounting in small and medium sized Japanese companies: an exploratory study. Accounting and Business Research, 30(1), pp. 73-86.

Hussey, J. and Hussey, R. (1997). Business Research, Macmillan, Basingstoke.

Jarvis, R., Kitching, J., Curran, J. and Lightfoot, G. (2000). The use of quantitative and qualitative criteria in the measurement of performance in small firms. Journal of Small Business \& Enterprise Development, 7(2), pp. 123-34.

McMahon, R.G.P. (1998). Financial reporting practices of Australian manufacturing SMEs. School of Commerce Research Paper Series: 98-8, The Flinders University of South Australia. http://commerce.flinders.edu.au/researchpapers/98-8.htm[accessed 15 September 2005].

(2001). Business growth and performance and the financial reporting practices of Australian manufacturing SMEs. Journal of Small Business Management, 39(2), pp. 152-64.

and Davies, L.G. (1994). Financial reporting and analysis practices in small enterprise: Their association with growth rate and financial performance. Journal of Small Business Management, 32(1), pp. 9-17.

and Holmes, S. (1991). Small business financial management practices in North America: a literature review, Journal of Small Business Management, 29(2), pp. 1929.

Nayak, A. and Greenfield, S., (1994). The use of management accounting information for managing micro businesses, In Hughes, A. and Storey, D.J. (eds.), Finance and the Small Firms, London.

Sulaiman, M, Ahmad, Nik Nazli, and Alwi, M.N. (2004). Management accounting practices in selected Asian countries, Managerial Auditing Journal, 19 (4), pp. 493-508.

Sulaiman, M, Ahmad, Nik Nazli;., and Alwi, M.N. (2005), Is standard costing obsolete? Empirical evidence from Malaysia, Managerial Auditing Journal, 29 (2), pp. 109124.

Tho, S.L.M, Isa C.R., and Ng, K.T. (1998). Manufacturing environment, cost structures and management accounting practices: some Malaysian evidence, Akauntan Nasional, August, pp. 3-12. 